\title{
PENGARUH CORPORATE GOVERNANCE TERHADAP MANAJEMEN LABA
}

\author{
Hastuti Widyaningsih \\ STIEBBANK Yogyakarta \\ monikahwidya@gmail.com
}

\begin{abstract}
Abstrak: Pengaruh Corporate Governance Terhadap Manajemen Laba. Tujuan utama dari penelitian ini adalah meneliti hubungan antara corporate governance, yang diukur dengan kepemilikan institusional, kepemilikan manajerial, kepemilikan asing, dan komisaris independen, terhadap manajemen laba. Dengan menggunakan sampel dari perusahaan manufaktur yang terdaftar di Bursa Efek Indonesia selama periode 2013-2015. Penelitian ini menemukan bukti bahwa kepemilikan manajerial dan kepemilikan asing memiliki pengaruh terhadap manajemen laba, sedangkan kepemilikan institusional dan komisaris independen tidak memiliki pengaruh terhadap manajemen laba.
\end{abstract}

Kata kunci: corporate governance, kepemilikan institusional, kepemilikan manajerial, kepemilikan asing, komisaris independen, manajemen laba

Abstrack: The Effect of Corporate Governance on Earnings Management. The main objective of this paper is to investigate the relationship between corporate governance, measured by institutional ownership, managerial ownership, foreign ownership, independent commissioner, and earnings management. Using a sample of manufacturer companies listed on Indonesian Stock Exchange in the period 2013-2015. The research find that managerial ownership and foreign ownership have an impact on earnings management, whereas institutional ownership and independent commissioner don't have an impact on earnings management.

Keywords: corporate governance, institutional ownership, managerial ownership, foreign ownership, independent commissioner, earnings management.

\section{PENDAHULUAN}

Paper ini mendiskusikan hasil penelitian empiris yang menginvestigasi pengaruh corporate governance terhadap manajemen laba. Riset ini dimotivasi oleh hasil penelitian terdahulu tentang corporate governance yang mayoritas dilakukan untuk menilai aspek kepemilikan manajerial, kepemilikan institusional, serta komisaris independen, sedangkan penelitian tentang aspek kepemilikan asing belum banyak diteliti.
Kepemilikan manajerial timbul dari adanya hubungan keagenan antara prinsipal dan agen untuk mendelegasikan pembuatan keputusan kepada agen. (Jensen and Meckling, 1976). Beberapa penelitian terdahulu memperlihatkan hubungan yang positif antara kepemilikan manajerial dan earnings management (Cheng dan Warfield, 2005; Bergstresser dan Philippon, 2006; Baber et al, 2009; Baek, H Young et al. 2009). Penelitian yang lain memperlihatkan hubungan 


\section{JURNAL NOMINAL / VOLUME VI NOMOR 2 / TAHUN 2017}

yang negatif atau tidak adanya hubungan antara keduanya (Hribar and Nichols, 2007). Kepemilikan saham oleh manajemen merupakan salah satu bentuk insentif yang diberikan oleh pemilik kepada manajemen. (Jensen dan Murphy, 1990). Kepemilikan saham oleh investor institusional dapat memonitor manajemen, sehingga motivasi manajer untuk melakukan earnings management menjadi berkurang. Hubungan antara kepemilikan institusional dengan peningkatan discretionary accrual perusahaan berbeda pada level tingkatan kepemilikan institusional. (Koh, 2003).

Penelitian terhadap perusahaanperusahaan Jepang dilakukan untuk mengetahui apakah investor asing menggunakan pengaruh yang signifikan pada earnings management melalui manipulasi terhadap aktivitas riil. Hasil penelitian menemukan bahwa investor asing memainkan peran independen dalam menahan earnings management yang bersifat riil, yang dilakukan melalui arus kas operasi yang tidak normal, beban discretionary yang tidak normal, maupun biaya produksi yang tidak normal. (Guo et al, 2015)

Penyertaan proporsi yang lebih besar dari 'outside members' pada dewan direksi secara signifikan mengurangi kemungkinan dari terjadinya fraud pada laporan keuangan.
Kehadiran komite audit tidak secara signifikan mempengaruhi kemungkinan terjadinya kecurangan pada laporan keuangan. (Beasley, 1996). Dengan peningkatan kepemilikan 'outside directors' dalam perusahaan dan masa jabatan 'outside directors', maka kemungkinan terjadinya fraud dalam laporan keuangan akan menurun (Fama dan Jensen, 1983) dan komisaris independen dapat bertindak sebagai penengah dalam perselisihan yang terjadi diantara para manajer internal dan mengawasi kebijakan manajemen serta memberikan nasihat kepada manajemen. Komisaris independen merupakan posisi terbaik untuk melaksanakan fungsi monitoring agar tercipta perusahaan yang good corporate governance. Jika anggota dewan komisaris dari luar meningkatkan tindakan pengawasan, hal ini juga akan berhubungan dengan makin rendahnya penggunaan discretionary accruals (Cornett et al., 2006). Perusahaan dengan jumlah dewan yang kecil memperlihatkan nilai yang lebih baik pada rasio keuangan, dan menyediakan insentif kinerja CEO yang lebih kuat. (Yermarck, 1996)

\section{Good Corporate Governance} diperkenalkan pertama kali oleh Cadbury Committee tahun 1992 dalam laporannya yang dikenal sebagai Cadbury Report (Tjager, 2003). 


\section{JURNAL NOMINAL / VOLUME VI NOMOR 2 / TAHUN 2017}

Definisi Good Corporate Governance dari Cadbury Committee yang berdasar pada teori stakeholder adalah sebagai berikut: "A set of rules that define the relationship between shareholders, managers, creditors, the government, employees, and internal and external stakeholders in respect to their rights and responsibilities". (Seperangkat aturan yang mengatur hubungan antara para pemegang saham, manajer, kreditur, pemerintah, karyawan, dan pihak-pihak yang berkepentingan lainnya baik internal maupun eksternal lainnya yang berkaitan dengan hak dan kewajiban). Menurut Surat Keputusan Menteri Negara/Kepala Badan Penanaman Modal dan Pembinaan BUMN No. 23/M PM/BUMN/2000 tentang Pengembangan Praktik GCG dalam Perusahaan Perseroan (PERSERO), Good Corporate Governance adalah prinsip korporasi yang sehat yang perlu diterapkan dalam pengelolaan perusahaan yang dilaksanakan semata-mata demi menjaga kepentingan perusahaan dalam rangka mencapai maksud dan tujuan perusahaan. Penerapan mekasnisme corporate governance dapat dilakukan melalui mekanisme monitoring yaitu: memperbesar kepemilikan saham oleh pihak manajemen (kepemilikan manajemen), kepemilikan institusional, kepemilikan asing, serta mengangkat dewan komisaris

Mekanisme corporate governance yang kuat diharapkan dapat menekan terjadinya earnings management. Terjadinya manajemen laba disebabkan oleh keputusan manajemen untuk mengubah laporan keuangan, yang dapat berakibat menyesatkan para stakeholder (Healey dan Wahlen, 1999). Manajemen laba terjadi karena adanya asimetri informasi, dimana pada saat asimetri informasi tinggi, para stakeholder tidak memiliki sumber, insentif, atau akses yang cukup terhadap informasi yang relevan untuk memonitor tindakan manajer, yang dapat meningkatkan praktik earnings management. Para manajer berusaha untuk melakukan manipulasi terhadap kinerja perusahaan yang mereka tangani untuk mendapatkan insentif bagi diri mereka sendiri (Morris, 1987). Fenomena terjadinya earnings management di Indonesia cenderung merupakan earnings management yang efisien. (Veronica dan Utama, 2008). Kepemilikan keluarga memiliki pengaruh yang signifikan terhadap jenis earnings management yang dipilih. Perusahaan dengan proporsi kepemilikan perusahaan yang tinggi lebih cenderung memilih earnings 


\section{JURNAL NOMINAL / VOLUME VI NOMOR 2 / TAHUN 2017}

management bentuk efisien dibanding jenis perusahaan yang lain.

Penelitian ini dilakukan untuk menjawab pertanyaan penelitian, yaitu apakah keempat komponen dari good corporate governance, yaitu kepemilikan institusional, kepemilikan manajerial, kepemilikan asing, serta komisaris independen berpengaruh terhadap earnings management. Dengan menggunakan sampel perusahaan manufaktur yang terdaftar di Bursa Efek Indonesia (BEI), diperoleh hasil bahwa kepemilikan manajemen dan kepemilikan asing memiliki pengaruh terhadap earnings management. Dalam penelitian ini, variabel leverage, profitabilitas, dan ukuran perusahaan diperlakukan serbagai variabel kontrol.

Bagian berikutnya paper ini menyajikan rerangka teoritis dan pengembangan hipotesis serta dilanjutkan dengan menyajikan metode penelitian. Setelah mendeskrisikan hasil analisis data dan pembahasan, paper ini ditutup dengan kesimpulan, dan saran.

\section{Rerangka Teoritis}

Earnings management terjadi pada saat para manajer menggunakan judgement dalam pelaporan keuangan dan dalam penataan transaksi untuk mengubah laporan keuangan yang bertujuan untuk menyesatkan para

stakeholders tentang kinerja keuangan perusahaan atau untuk mempengaruhi hasil yang tergantung pada angka-angka akuntansi yang dilaporkan. (Healy dan Wahlen, 1999). Pada saat melakukan deteksi atas ada atau tidaknya earnings management pada sebuah perusahaan seharusnya dikaitkan dengan kinerja keuangan, dan versi modifikasi dari model Jones (1991) merupakan model yang terbaik dalam mengukur earnings management (Dechow, el al, 1995). Perusahaan melakukan manajemen laba untuk mencegah terjadinya penurunan earning dan kerugian (Burgstahler dan Dichev, 1997).

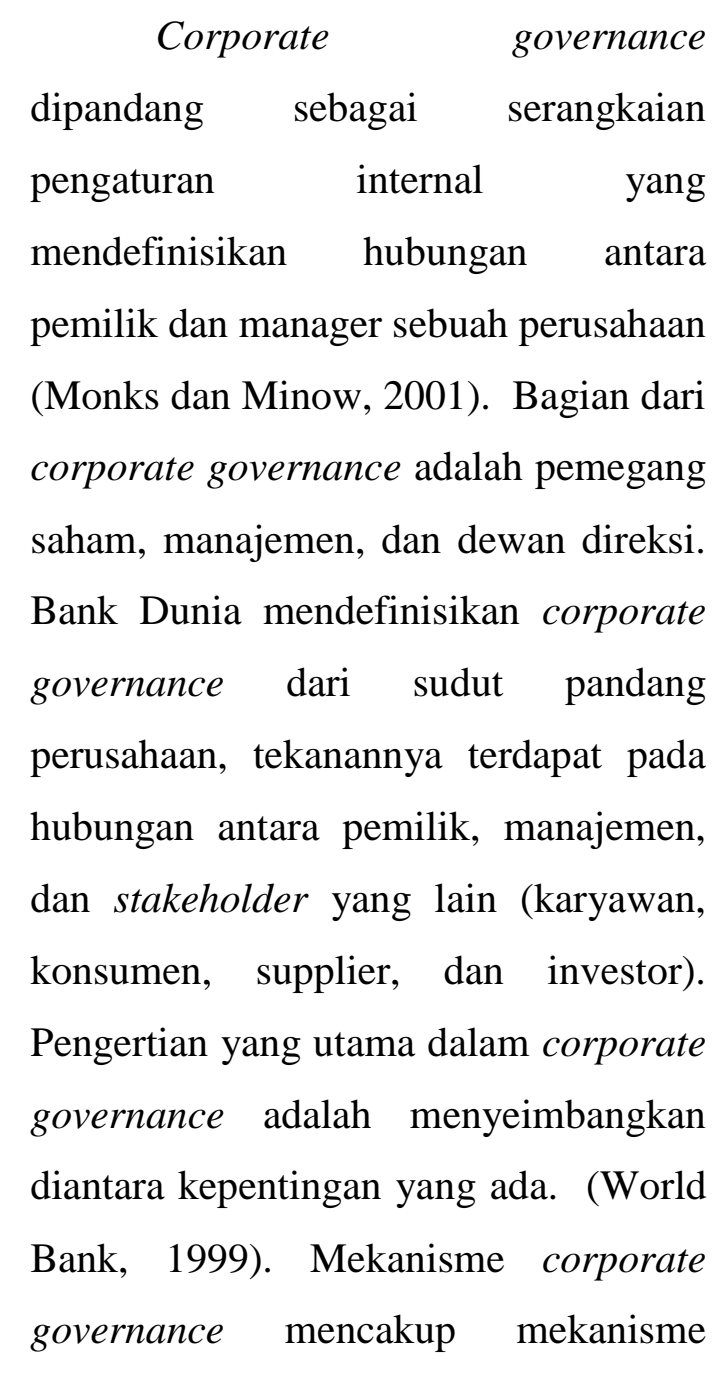




\section{JURNAL NOMINAL / VOLUME VI NOMOR 2 / TAHUN 2017}

internal dan eksternal. Mekanisme internal corporate governance meliputi : konsentrasi kepemilikan, dewan direksi, cara untuk memberikan penghargaan kepada manager, dan struktur organsiasi yang multidivisional. Mekanisme eksternal corporate governance meliputi pasar bagi pengendalian perusahaan. (Babic dan Janosevic, 2001).

\section{Pengembangan Hipotesis}

Kepemilikan Institusional dan Manajemen Laba

Jensen dan Meckling (1976) menyebutkan bahwa kepemilikan institusional dapat mengurangi konflik kepentingan antara manajemen dan pemilik perusahaan. Kepemilikan institusional tidak mudah percaya terhadap perilaku manajemen laba yang dilakukan oleh manajemen. Kepemilikan institusional adalah kepemilikan saham perusahaan oleh perusahaan asuransi, bank, dan perusahaan investasi. Penelitian yang dilakukan pada perusahaan di Taiwan memperlihatkan bahwa kepemilikan investor institusional memainkan peran yang penting dalam membentuk real earnings management (Lan Liu dan Tsai, 2015), sedangkan penelitian yang dilakukan pada perusahaan di Portugal menunjukkan bukti bahwa discretionary accrual sebagai proksi dari earnings management secara negatif berhubungan dengan kepemilikan manajerial (Alves, 2012). Hasil yang lain diperoleh dari penelitian yang dilakukan di Nigeria yang memperlihatkan hasil bahwa terdapat hubungan yang positif antara kepemilikan investor institusional dengan earnings management (Isenmila dan Elijah, 2012).

Faroog dan Jai (2012) dalam penelitiannya yang mengambil bukti dari Pasar Modal Casablanca memperoleh bukti bahwa perusahaan dengan pemegang saham terbesar berupa institusi asing atau lokal memperlihatkan pengaruh yang lebih rendah terhadap earnings management daripada perusahaan lain. Hasil ini konsisten dengan penelitian yang dilakukan oleh Lin dan Manowan (2012) meneliti dua aspek kepemilikan institusional, yaitu kepemilikan institusional sementara dan kepemilikan institusional tetap (dengan tingkat perputaran yang rendah) dan menemukan hubungan yang positif signifikan antara kepemilikan investor institusional sementara dengan discretionary accounting accrual, serta hubungan yang negatif dan tidak signifikan antara kepemilikan investor institusional tetap dengan discretionary accounting accruals. Hal ini konsisten dengan hasil yang menunjukkan bahwa peran yang tidak signifikan dari 


\section{JURNAL NOMINAL / VOLUME VI NOMOR 2 / TAHUN 2017}

kepemilikan institusi dan block-holder dalam memonitor perilaku manajerial dalam earnings management, dan memberikan hasil bahwa penerapan prinsip-prinsip corporate governance dalam memotivasi institusi dan blockholders untuk menyediakan monitoring yang efektif dari para manajer dalam perusahaan Yordania (Al-Fayoumi et al, 2010).

Penelitian yang dilakukan pada perusahaan Perancis memperlihatkan hasil yaitu kepemilikan institusional memiliki pengaruh positif terhadap informasi earnings (Ayadi dan Boujelbene, 2014). Hasil penelitian yang dilakukan pada perusahaan di Yordania oleh Ramadan (2015) memperlihatkan hasil bahwa kepemilikan manajemen dan investor institusional berhubungan secara terbalik dengan praktik-praktik earnings management. Hasil yang lain diperlihatkan oleh penelitian yang dilakukan oleh Al-Zyoud (2012) yang memperlihatkan hasil bahwa investor institusional memberikan kontribusi dalam membatasi earnings management. Hasil yang berbeda diperlihatkan oleh penelitian yang dilakukan oleh Ajay (2015) yang menunjukkan hasil bahwa kepemilikan foreign institutional memiliki hubungan negatif dengan earnings management.
Berdasarkan uraian tersebut, maka hipotesis yang diajukan sebagai berikut:

$$
\mathrm{H}_{1} \text { : Terdapat pengaruh }
$$
mekanisme good corporate governance dengan proksi kepemilikan institusional terhadap manajemen laba

\section{Kepemilikan Manajerial dan Manajemen Laba}

Kepemilikan manajerial merupakan pemisahan kepemilikan antara pihak dalam dan pihak luar perusahaan. Jika dalam sebuah perusahaan memiliki pemilik saham yang banyak, maka kelompok besar individu tersebut tidak dapat berpartisipasi secara aktif dalam manajemen perusahaan. Kepemilikan manajerial adalah persentase saham yang berkaitan dengan saham yang dimiliki oleh dewan komisaris dalam sebuah perusahaan. Hubungan yang positif konsisten dengan fakta bahwa peningkatan dalam harga saham meningkatkan nilai portfolio dari manajemen dengan kepemilikan saham yang tinggi daripada manajemen dengan nilai kepemilikan yang rendah (the reward effect) (Quinn, 2016). Penelitian yang dilakukan pada perusahaan di Malaysia memperlihatkan hasil bahwa kepemilikan saham diatas $25 \%$ dapat mendorong manajemen untuk mengatur laba, dan kombinasi peran CEO (COE duality) tidak mempengaruhi praktek earnings 


\section{JURNAL NOMINAL / VOLUME VI NOMOR 2 / TAHUN 2017}

management pada perusahaan Malaysia

(Johari et al, 2008). Hasil tersebut konsisten dengan penelitian yang dilakukan oleh Ogbonnaya (2016) yang melakukan penelitian pada perusahaan yang berada pada Industri Brewery dan memperlihatkan hasil bahwa kepemilikan CEO dan manajerial memiliki pengaruh yang positif signifikan terhadap earnings management. Konsisten dengan penelitian yang dilakukan pada perusahaan di Jordan yang memperlihatkan hasil bahwa kepemilikan insider bersifat signifikan dan positif mempengaruhi earnings management (Fayoumi et al, 2010). Hasil yang berbeda ditunjukkan oleh temuan bahwa kepemilikan manajemen dan kualitas audit, keduanya berhubungan terbalik dengan abnormal accruals (Jen-You et al, 2003). Hasil ini konsisten dengan penelitian yang dilakukan di Yordania bahwa kepemilikan manajemen berhubungan secara terbalik dengan praktik manajemen laba (Ramadan, 2015). Penelitian yang dilakukan di Malaysia kembali menemukan hasil bahwa kepemilikan manajemen berhubungan secara negatif dengan besarnya accounting accruals (Mohd Ali et al, 2008). Hasil penelitian pada perusahaan di Amerika Serikat memperlihatkan bukti yang berbeda dengan penelitian yang lain dimana tidak terdapat hubungan yang signifikan antara kepemilikan manajerial dan earnings management (Spinos, 2013). Yih Yang et al (2008) menemukan bahwa discretionary accruals secara positif dipengaruhi oleh director ownership dan blockholder ownership. Penelitian yang dilakukan oleh AlZyoud (2012) memperlihatkan hasil bahwa kepemilikan manajemen tidak memberikan kontribusi dalam membatasi earnings management. Fayoumi et al (2010) menemukan bahwa peran yang tidak signifikan dari kepemilikan institusi dan block-holder dalam memonitor perilaku manajerial dalam earnings management, dan memberikan hasil bahwa penerapan prinsip-prinsip corporate governance dalam memotivasi institusi dan blockholders untuk menyediakan monitoring yang efektif dari para manajer dalam perusahaan Yordania. Hasil ini sejalan dengan bukti penelitian yang diperoleh dari perusahaan di Taiwan memperlihatkan bahwa kepemilikan manajerial tidak memiliki hubungan antara tingkat kepemilikan dengan real earnings management (Liu, 2015). Penelitian yang dilakukan oleh Alves (2012) pada perusahaan di Portugal memberikan hasil bahwa discretionary accrual sebagai proksi earnings management secara negatif 


\section{JURNAL NOMINAL / VOLUME VI NOMOR 2 / TAHUN 2017}

berhubungan dengan kepemilikan manajerial.

Hasil yang berbeda diperoleh dari penelitian terhadap perusahaan di Nigeria yang memperoleh bukti bahwa hubungan antara insider ownership dan earnings management bersifat positif dan signifikan pada level signifikansi 5\% (Isenmila dan Elijah, 2012). Konsisten dengan hasil yang diperoleh dari perusahaan di Perancis yang menghasilkan bukti bahwa kepemilikan manajemen memiliki dampak positif terhadap earnings management (Ayadi dan Boujelbene, 2014). Berdasarkan uraian tersebut, maka hipotesis yang diajukan sebagai berikut:

$\mathrm{H}_{2}$ : Terdapat pengaruh mekanisme good corporate governance dengan proksi kepemilikan manajemen terhadap manajemen laba

Kepemilikan Asing dan Manajemen Laba

Menurut UU No. 25 Tahun 2007 tentang Penanaman Modal, dijelaskan bahwa penanaman modal asing adalah kegiatan menanam modal untuk melakukan usaha di wilayah negara Republik Indonesia yang dilakukan oleh penanam modal asing, baik yang menggunakan modal asing sepenuhnya maupun yang berpatungan dengan penanam modal dalam negeri. Penelitian yang dilakukan oleh Ajay (2015) menunjukkan hasil bahwa kepemilikan foreign institutional memiliki hubungan negatif dengan earnings management. Hasil ini konsisten dengan penelitian lain yang dilakukan di Jepang yang memperlihatkan hasil bahwa perusahaan dengan kepemilikan asing yang lebih tinggi melakukan real earnings management yang lebih kecil (Kim, 2015). Penelitian lain terhadap perusahaan-perusahaan Jepang meneliti apakah investor asing menggunakan pengaruh yang signifikan pada earnings management melalui manipulasi terhadap aktivitas riil. Hasil penelitian menemukan bahwa investor asing memainkan peran independen dalam menahan earnings management yang bersifat riil, yang dilakukan melalui arus kas operasi yang tidak normal, beban discretionary yang tidak normal, maupun biaya produksi yang tidak normal. (Guo et al, 2015). Berdasarkan uraian tersebut, maka hipotesis yang diajukan sebagai berikut:

$\mathrm{H}_{3}$ : Persentase kepemilikan asing berpengaruh terhadap manajemen laba

\section{Komisaris Independen dan}

\section{Manajemen Laba}

Komisaris independen adalah anggota komisaris yang tidak terafiliasi dengan manajemen, anggota dewan komisaris lainnya dan pemegang saham pengendali, serta bebas dari hubungan bisnis dan hubungan lainnya yang dapat 


\section{JURNAL NOMINAL / VOLUME VI NOMOR 2 / TAHUN 2017}

mempengaruhi kemampuannya untuk bertindak independen atau bertindak semata-mata demi kepentingan perusahaan (Komite Nasional Kebijakan Good Corporate Governance 2006). Keberadaan komisaris independen dalam perusahaan berfungsi sebagai penyeimbang dalam proses pengambilan keputusan guna memberikan perlindungan terhadap pemegang saham minoritas dan pihakpihak lain yang terkait dengan perusahaan. Struktur dewan yang lebih independen dari CEO lebih efektif dalam memonitor proses akuntansi keuangan perusahaan. (Klein, 2002). Hasil penelitian lain mengindikasikan bahwa kemungkinan para manajer melakukan income-inreasing abnormal accrual untuk mencegah pelaporan kerugian dan penurunan earning secara negatif berhubungan dengan proporsi dari outsiders pada dewan direksi. Juga ditemukan bahwa peluang perubahan abnormal accruals yang melaporkan rugi menjadi laba secara signfikan terjadi rendah pada perusahaan dengan proporsi outside board members yang lebih rendah (Peasnell, KV et al, 2005). Penelitian yang dilakukan oleh AlZyoud (2012) menemukan bukti bahwa independent chairman tidak memiliki pengaruh dalam mendeteksi earnings management Chen et al (2011) menemukan bahwa perusahaan dengan jumlah komisaris independen mayoritas mengalami penurunan yang signifikan dalam earnings management.

Penelitian yang dilakukan dengan mengambil bukti perusahaan di Mesir memperlihatkan hasil bahwa jumlah komisaris independen yang lebih tinggi efektif dalam mengurangi earnings management (Khalil, 2013). Bukti yang diperoleh dari perusahaan di Portugis memperlihatkan hasil bahwa anggota komisaris independen meningkatkan kualitas earnings dengan mengurangi earnings management (Alves, 2014). Berdasarkan uraian tersebut, maka hipotesis yang diajukan sebagai berikut:

$\mathrm{H}_{4}$ : Terdapat pengaruh mekanisme good corporate governance dengan proksi komisaris independen terhadap manajemen laba

Variabel Pengendali: Leverage, Profitabilitas, dan Ukuran Perusahaan

Leverage adalah perbandingan antara total kewajiban dengan total aktiva perusahaan. Rasio ini menunjukkan besarnya aktiva yang dimiliki perusahaan yang dibiayai dengan hutang. Semakin tinggi nilai leverage maka risiko yang akan dihadapi investor akan semakin tinggi dan para investor akan meminta keuntungan yang semakin besar. Oleh karena itu, semakin besar leverage maka kemungkinan manajer untuk 
JURNAL NOMINAL / VOLUME VI NOMOR 2 / TAHUN 2017

melakukan manajemen laba akan semakin besar. Profitabilitas merupakan suatu indikator kinerja manajemen dalam mengelola kekayaan perusahaan yang ditunjukkan oleh laba yang dihasilkan perusahaan (Sudarmadji dan Sularto, 2007). Laba yang dihasilkan perusahaan selama tahun berjalan dapat menjadi indikator terjadinya praktik manajemen laba dalam suatu perusahaan. Biasanya manajemen laba dilakukan oleh manajer untuk memanipulasi komponen laba rugi yang dilaporkan perusahaan. Ukuran perusahaan dapat dinyatakan dalam total aktiva, penjualan dan kapasitas pasar. Ketiga pengukuran tersebut seringkali digunakan untuk mengidentifikasi ukuran suatu perusahaan karena semakin besar aktiva yang dimiliki oleh perusahaan, maka semakin besar modal yang ditanam. Semakin besar jumlah penjualan, maka semakin besar pula perputaran uang di perusahaan tersebut, dan semakin besar kapitalisasi pasar maka perusahaan tersebut semakin dikenal oleh masyarakat (Sudarmadji dan Sularto 2007).

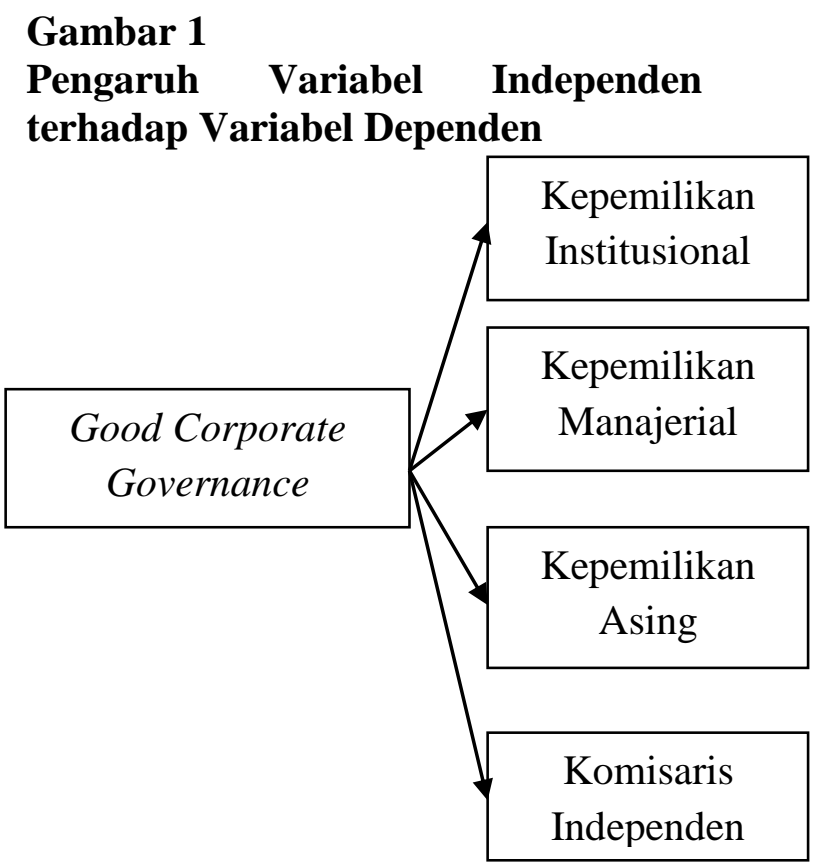

\section{METODE PENELITIAN}

Obyek penelitian yang digunakan adalah perusahaan manufaktur yang terdaftar di Bursa Efek Indonesia selama periode 2013 sampai dengan 2015. Pemilihan sampel menggunakan metode purposive sampling, yang dipilih berdasarkan kriteria perusahaan manufaktur yang terdaftar di Bursa Efek Indonesia minimal sejak Desember 2012 dan tidak mengalami delisting selama periode penelitian, menggunakan mata uang Rupiah dalam laporan keuangannya, memiliki akhir tahun buku 31 Desember dalam laporan keuangannya, melaporkan net income dan operating income serta arus kas positif dari Kepemilikan manajemen merupakan saham yang dimiliki oleh manajemen secara pribadi maupun saham yang dimiliki oleh manajemen secara pribadi maupun saham yang 
JURNAL NOMINAL / VOLUME VI NOMOR 2 / TAHUN 2017

dimiliki oleh anak cabang perusahaan bersangkutan beserta afiliasinya (Susiana dan Herawaty, 2007). Kepemilikan manajemen diukur menggunakan skala rasio melalui persentase jumlah saham yang dimiliki pihak manajemen dari seluruh modal saham perusahaan yang beredar.

$$
\text { MNJMN }=\frac{\text { Jml saham manajemen }}{\text { Modal saham perusahaan }}
$$

\section{Kepemilikan Asing}

Kepemilikan asing mengarah kepada kepemilikan mayoritas atau pengendalian dari suatu bisnis atau sumber dalam suatu negara oleh individu yang bukan merupakan warga negara atau oleh perusahaan yang kantor pusatnya tidak berada pada negara tersebut.

$\mathrm{KA}=\underline{\text { Jumlah }}$ saham investor asing

Modal saham perusahaan

\section{Komisaris Independen}

Komisaris independen diukur dengan menggunakan skala rasio melalui persentase anggota dewan komisaris yang berasal dari luar perusahaan dari seluruh ukuran anggota dewan komisaris perusahaan.

$\mathrm{KI}=\underline{\text { Jumlah dewan komisaris dari }}$ $\underline{\text { luar }}$

Anggota dewan komisaris
Leverage

Leverage diukur dengan menggunakan skala rasio total hutang terhadap total asset.

$$
\text { Leverage }=\frac{\text { Total Hutang }}{\text { Total Asset }}
$$

\section{Profitabilitas}

Profitabilitas merupakan kemampuan perusahaan dalam menghasilkan laba. Profitabilitas dalam penelitian ini diukur dengan skala rasio Return on Assets (ROA) yaitu perbandingan antara laba bersih sebelum pajak terhadap total aset.

Profitabilitas $=\underline{\text { Laba bersih sblm pajak }}$ Total Aset

\section{Ukuran Perusahaan}

Ukuran perusahaan diukur dengan menggunakan hasil logaritma dari total aset. Total aset digunakan sebagai proksi ukuran perusahaan dengan pertimbangan total aset perusahaan relatif lebih stabil dibandingkan dengan jumlah penjualan dan nilai kapitalisasi pasar.

\section{Model Penelitian}

Proksi yang digunakan untuk manajemen laba dalam penelitian ini merupakan modifikasi cross sectional dari model Jones, (1991), yang dapat mendeteksi manajemen laba secara konsisten (Sanjay, 2008). Rumus yang digunakan untuk menentukan nilai total accruals untuk sampel perusahaan yang terpilih dengan pendekatan cash flow 
JURNAL NOMINAL / VOLUME VI NOMOR 2 / TAHUN 2017

dijelaskan sebagai berikut. Setelah diperoleh nilai total accruals, dilakukan regresi untuk memperoleh angka koefisien $\alpha_{1}, \alpha_{2}$, dan $\alpha_{3}$, dengan variabel dependen total accruals dan variabel independen adalah total aset tahun sebelumnya (t-1), perubahan pendapatan, dan total asset tetap kotor perusahaan pada tahun ke-t. Setelah diperoleh nilai koefisien regresi $\alpha_{1}, \alpha_{2}$, dan $\alpha_{3}$, maka dilanjutkan dengan menghitung komponen nondiscretionary accruals. Model nondiscretionary accruals dirumuskan sebagai berikut:

NDA $=$ TA -

DA

DA $=\mathrm{TA}-$

NDA

Alat analisis yang digunakan untuk menguji hipotesis adalah multiple regression analysis dengan model persamaan sebagai berikut:

$\mathrm{DA}=\beta_{0}+\beta_{1} \mathrm{INST}+\beta_{2} \mathrm{MNJM}+$ $\beta_{3} \mathrm{KA}+\beta_{4} \mathrm{KI}+\beta_{5} \mathrm{LEV}+\beta_{6} \mathrm{ROA}+$ $\beta_{7} \mathrm{SIZE}+\varepsilon$

Keterangan :

DA : Discretionary Accruals

INST : Kepemilikan Institusional MNJMN：Kepemilikan Manajemen

KA : Kepemilikan asing

KI : Komisaris Independen

LEV : Leverage

ROA : Return on Asset
SIZE : Ukuran Perusahaan berupa $\log$ Total Aset

$\varepsilon \quad:$ Error term

\section{Analisis Data dan Diskusi}

Tabel 1 berikut ini menggambarkan hasil dari statistik deskriptif. Sebelum dilakukan pengolahan data, peneliti melakukan pemeriksaan awal terhadap data untuk mengidentifikasi ada tidaknya outlier. Selanjutnya, dilakukan pengujian asumsi klasik. Hasil pengujian menunjukkan bahwa tidak ada pelanggaran yang cukup berarti pada normalitas, otokorelasi, multikolinieritas, dan heteroskedastisitas.

Tabel 1. Statistik Deskriptif

\begin{tabular}{|c|c|c|c|c|c|}
\hline & $\begin{array}{c}\text { Mea } \\
\mathrm{n}\end{array}$ & $\begin{array}{c}\text { Media } \\
\mathrm{n}\end{array}$ & $\begin{array}{c}\text { Maximu } \\
\mathrm{m}\end{array}$ & $\begin{array}{c}\text { Minimu } \\
\mathrm{m}\end{array}$ & $\begin{array}{l}\text { Std. } \\
\text { Dev. }\end{array}$ \\
\hline DA & $\begin{array}{r}- \\
0.04 \\
6\end{array}$ & 0.010 & 13.330 & -14.915 & 1.528 \\
\hline INS & $\begin{array}{r}0.61 \\
6\end{array}$ & 0.651 & 0.997 & 0.000 & 0.275 \\
\hline MNJ & $\begin{array}{r}0.06 \\
6\end{array}$ & 0.000 & 0.873 & 0.000 & 0.187 \\
\hline KA & $\begin{array}{r}0.33 \\
4\end{array}$ & 0.205 & 0.997 & 0.000 & 0.349 \\
\hline KI & $\begin{array}{r}0.41 \\
2\end{array}$ & 0.400 & 0.667 & 0.167 & 0.099 \\
\hline LEV & $\begin{array}{r}8.76 \\
6\end{array}$ & 0.491 & 881.687 & -0.067 & $\begin{array}{r}81.59 \\
7\end{array}$ \\
\hline $\begin{array}{l}\text { SIZ } \\
\text { E }\end{array}$ & $\begin{array}{r}6.27 \\
2\end{array}$ & 6.174 & 7.963 & 4.993 & 0.670 \\
\hline $\begin{array}{l}\text { RO } \\
\text { A }\end{array}$ & $\begin{array}{r}0.08 \\
5\end{array}$ & 0.045 & 1.051 & -0.296 & 0.163 \\
\hline
\end{tabular}

Untuk menguji apakah masingmasing variabel berpengaruh positif terhadap manajemen laba, peneliti melakukan analisis regresi korelasi. Hasil analisis disajikan pada tabel 2. 
JURNAL NOMINAL / VOLUME VI NOMOR 2 / TAHUN 2017

Tabel 2. Analisis Regresi-Korelasi

\begin{tabular}{crrl}
\hline DA $=\beta 0$ & $+\beta 1$ INST $+\beta 2$ MNJM $+\beta 3 \mathrm{KA}+$ \\
\multicolumn{4}{c}{$\beta 4 \mathrm{KI}+\beta 5 \mathrm{LEV}+\beta 6 \mathrm{ROA}+\beta 7$} \\
SIZE $+\varepsilon(1)$ \\
\hline Variable & Coefficient & $\begin{array}{c}\mathrm{t}- \\
\text { Statistic }\end{array}$ & Prob. \\
\hline $\mathrm{C}$ & 0.204719 & 2.003998 & 0.0460 \\
$\mathrm{INS}$ & 0.039288 & 1.539265 & 0.1248 \\
$\mathrm{MNJ}$ & -0.055894 & - & 0.0022 \\
& & 3.085598 & \\
$\mathrm{KA}$ & -0.173540 & - & 0.0000 \\
& & 11.05922 & \\
$\mathrm{KI}$ & 0.016592 & 0.162435 & 0.8711 \\
LEV & $4.14 \mathrm{E}-06$ & 0.375532 & 0.7075 \\
SIZE & -0.030007 & - & 0.0001 \\
& & 4.081911 & \\
ROA & 0.138978 & 1.106716 & 0.2693 \\
\hline
\end{tabular}

Pada tabel 2 dapat dilihat bahwa

koefisien MNJ bernilai positif signifikan $(\mathrm{p}=0.000)$. Secara statistis, hal ini menunjukkan bahwa variabel MNJ dan KA berpengaruh signifikan terhadap variabel Manajemen Laba yang pada persamaan diwakili oleh variabel DA. Berdasarkan hasil tersebut dapat disimpulkan bahwa $\mathrm{H}_{2}$ didukung oleh data observasi. Hasil penelitian ini konsisten dan mengkonfirmasi penelitian yang dilakukan pada perusahaan di Malaysia memperlihatkan hasil bahwa kepemilikan saham diatas $25 \%$ dapat mendorong manajemen untuk mengatur earning, (Johari et al, 2008). Hasil tersebut konsisten dengan penelitian yang dilakukan oleh Ogbonnaya (2016) yang melakukan penelitian pada perusahaan yang berada pada Industri Brewery dan memperlihatkan hasil bahwa kepemilikan CEO dan managerial memiliki pengaruh yang positif signifikan terhadap earnings management. Penelitian yang dilakukan pada perusahaan di Jordan yang memperlihatkan hasil yang konsisten bahwa kepemilikan insider bersifat signifikan dan positif mempengaruhi earnings management (Fayoumi et al, 2010).

Penelitian ini juga ingin menguji apakah Kepemilikan Asing memiliki pengaruh signifikan terhadap variabel Manajemen Laba. Pada Tabel 2 dapat dilihat hasil bahwa koefisien KA berpengaruh signifikan terhadap variabel Manajemen Laba yang pada persamaan diwakili oleh variabel DA. Berdasarkan hasil tersebut dapat disimpulkan bahwa $\mathrm{H}_{3}$ didukung oleh data observasi. Hasil penelitian ini konsisten dan mengkonfirmasi penelitian yag dilakukan oleh penelitian yang dilakukan oleh Ajay (2015) menunjukkan hasil bahwa kepemilikan foreign institutional memiliki hubungan negatif dengan earnings management. Hasil ini konsisten dengan penelitian lain yang dilakukan di Jepang yang memperlihatkan hasil bahwa perusahaan dengan kepemilikan asing yang lebih tinggi mengalami real earnings management yang lebih kecil (Kim, 2015)

Pada penelitian ini pengajuan $\mathrm{H}_{1}$ dan $\mathrm{H}_{4}$ tidak terbukti, dimana koefisien variabel INS dan KI tidak mendukung 
JURNAL NOMINAL / VOLUME VI NOMOR 2 / TAHUN 2017

hipotesis penelitian, sehingga penelitian ini membuktikan variabel Kepemilikan Institusional tidak memiliki pengaruh terhadap Manajemen Laba, dan hasil yang sama juga ditunjukkan oleh hasil bahwa variabel Komite Independen tidak berpengaruh terhadap variabel Manajemen Laba.

\section{SIMPULAN DAN SARAN}

\section{Simpulan}

Temuan penelitian ini memberikan dukungan terhadap hasil bahwa Kepemilikan Manajemen serta Kepemilikan Asing memiliki pengaruh terhadap Manajemen Laba. Pengaruh Kepemilikan Manajemen terhadap Manajemen Laba mendukung penelitian yang telah dilakukan sebelumnya. Hasil penelitian yang memperlihatkan Pengaruh Kepemilikan Asing terhadap Manajemen Laba dapat memberikan kontribusi terhadap bukti empiris dimana belum banyak penelitian yang dilakukan dalam mendukung hasil tersebut.

\section{Saran-Saran}

Penelitian ini menguji pengaruh empat konsep corporate governance yaitu kepemilikan institusional, kepemilikan manajerial, kepemilikan asing, serta komisaris independen terhadap manajemen laba.
Pada penelitian selanjutnya dapat digunakan model earnings management dari aktivitas riil (Guo et al, 2015) serta dapat diperdalam pengaruh faktor corporate governance yang lain, terutama yang menyangkut faktor manajemen dan audit intern.

\section{DAFTAR PUSTAKA}

Ajay, Ranjitha dan R. Madhumathi. 2015. Institutional Ownership and Earnings Management in India. Indian Journal of Corporate Governance. 8 (2) : 119-136.

Al-Fayoumi, Nedal et al. 2010. Ownership Structure and Earnings Management in emerging Markets, The Case of Jordan. International Research Journal of Finance and Economics. 38.

Alves, Sandra. 2012. Ownership Structure and Earnings Management, Evidence from Portugal. Australian Accounting Business and Finance Journal. $6(1): 57-74$.

Alves, Sandra. 2014. The Effect of Board Independence on the Earnings Quality : Evidence from Portuguese Listed Companies. Australian Accounting Business and Finance Journal. 8(3) : 23-44.

Al-Zyoud, Abd Al Nasser. 2012. The Effects of Chairman Independence and Ownership Structure on Earnings Management. World Applied Sciences Journal, 17(8) : 934940. 


\section{JURNAL NOMINAL / VOLUME VI NOMOR 2 / TAHUN 2017}

Anand, Sanjay. 2008. Essentials of Corporate Governance. Hoboken: John Wiley and Sons.

Ayadi, Wafa Masmoudi. 2014. The Relationship between Ownership Structure and Earnings Quality in the French Context. International Journal of Accounting and Economis Studies. 2(2) : 80-87.

Baber, Wiliam. R et al. 2009. Shareholder Rights, Corporate Governance, and Accounting Restatement. SSRN.

Babic, V dan S Janosevic. 2001. "How to improve the Process of Strategic Change Management in Transition Economy Enterprises", Strategic Management Society, 21st Annual International Conference, San Francisco (2124 October), p. 10.

Baek, H Young et al. 2009. Managerial Ownership, Corporate Governane, and Voluntary Disclosure. The Journal of Business and Economic Studies. 15( 2) : 4461.

Beasley, Mark S. 1996. An Empirical Analysis of the Relation between the Board of Director Composition and Financial Statement Fraud. The Accounting Review. 71(4) : 443-465.

Bergstresser, Daniel dan Thomas Philippon. 2006. CEO Incentives and Ernings Management. Journal of Financial Economics. 80(3) : 511-529.

Burgstahler, David dan Ilia Dichev. 1997. Earnings Management to Avoid Earnings Decreases and
Loses. Journal of Accounting and Economics. 24(1):99-126.

Chen, Xia, et al. 2011. Does Increased Board Independence Reduce Earnings Management ? Evidence form Recent Regulatory Reforms. American Accounting Association Annual Meeting.

Cheng, Qiang dan Terry Warfield. 2005. Equity Incentives and Earnings Management. Accounting Review. 80(2):441476.

Cornett, Marcia M et al. 2006. Corporate Governance and Earnings Management at Large US Bank Holding Companies. SSRN.

Dechow, Patricia M, et al. 1995. Detecting Earnings Management. The Accounting Review. 70(2):193-225.

Fama, Eugene F dan Michael C Jensen. 1983. Separation of Ownership and Control. Journal of Law and Economics. 26(2):301-325.

Farooq, Omar dan Hind El Jai. 2012.

Ownership Structure and Earnings Management : Evidence from the Casablanca Stock Exchange. International Research Journal of Finance and Economics. 83:187-198.

Guo, Jun et al. 2015. Foreign Ownership and Real Earnings Management : Evidence from Japan. Journal of International Accounting Research. 14(2):185-213

Healey, Paul M dan James M Wahlen, 1999. A Review of The Earnings Management Literature and Its Implications for Standard Setting. Accounting Horizons. 13(4):365 
Hribar, Paul dan D Craig Nichols. 2007. The Use of Unsigned Earnings Quality Measures in Tests of Earnings Management. Journal of Accounting Reasearch. 45(5):1017-1053.

Isenmila, P.A dan Afensimi Elijah. 2012. Earnings Management an Ownership Structure : Evidence from Nigeria. Research Journal of Finance and Accounting. 3(7):2222-2847.

Jen-You, Shwu et al. 2003. Managerial Ownership, Audit Quality, and Earnings Management. Asia Pacific Management Review. 8(3):409-438.

Jensen, Michael C dan Kevin J Murphy. 1990. Performance Pay and Top-Management Incentives. The Journal of Political Economy. 98. (2):225-264.

Jensen, Michael $\mathrm{C}$ dan William $\mathrm{H}$ Meckling. 1976. Theory of The Firm :Managerial Behavior, Agency Costs and Ownership Structure. Journal of Financial Economics. 3(4):305-360.

Johari, Nor Hashimah et al. 2008. The Influence of Board Independence, Competency and Ownership on Earnings Management in Malaysia. Int. Journal of Economics and Management 2(2):281-306.

Khalil, Mohamed. 2012. Board Independence, Audit Quality and Earnings Management : Evidence from Eqypt. Working Paper.

Kim, Yongtae. Discussion of Foreign Ownership and Real Earnings Management : Evidence from Japan. Journal of International Accounting Research. Fall. 14(2):215-219.
Klein, April. 2002. Audit Committee, Board of Director Characteristics, and Earnings Management. Journal of Accounting and Economics. 33(3):375-400.

Koh, Ping Sheng. 2003. On the association between institutional ownership and aggressive corporate earnings management in Australia. The British Accounting Review. 35(2): 105128.

Komite Nasional Kebijakan Good Corporate Governance. 2006. Pedoman Umum Good Corporate Governance Indonesia. Jakarta.

Lan Liu, Jo dan Ching-Chieh Tsai. $2015 . \quad$ Board Member Characteristics and Ownership Structure Impacts on Real Earnings Management : Evidence from Taiwan. Accounting and Finance Research. 4(4):84-96.

Lin, Ling dan Pavinee Manowan. 2012. Institutional Ownership Composition and Earnings Management. Review of Pacific Basin Financial Markets and Policies. 15(4):1250022-11250022-22.

Mohd Ali, Salsiah et al. 2008. Ownership Structure and Earnings Management in Malaysian Listed Companies : The Size Effect. Asian Journal of Business and Accounting. 1(2):89-116.

Monks, Robert A.G dan Nell Minow. 2001. Corporate Governance. $5^{\text {th }}$ edition. John Wiley and Sons, Inc.

Morris, Richard D. 1987. Signalling, Agency Theory and Accounting Policy Choice. Journal of 
JURNAL NOMINAL / VOLUME VI NOMOR 2 / TAHUN 2017

Accounting and Business Research. 18(69):47-56.

Ogbonnaya, Amah Kalu et al. 2016. Effect of Corporate Governance and Ownership Structure on Earnings Management of Brewery Industry. European Journal of Accounting, Auditing, and Finance Research. 4(7):3545.

Peasnell, KV et al. 2005. Board Monitoring and Earnings Management : Do Outside Directors Influence Abnormal Accruals ? Journal of Business Finance and Accounting. 32(7):1311-1346.

Quinn, Phillip J. 2016. Managerial Ownership and Earnings Management : Evidence from Stock Ownership Plan. SSRN.

Ramadhan, Imad Zeyad. 2015. Does Ownership Structure Affect Jordanian Companies' Tendency to Practice Earnings Management ?. Asian Journal of Finance and Accounting. 7(2):281-291.

Spinos, Efstathios. 2013. Managerial Ownership and Earnings Management in Times of Financial Crisis : Evidence from USA. Thesis. Erasmus School of Economics.

Sudarmadji, A M dan Lana Sularto. 2007. Pengaruh Ukuran Perusahaan, Profitabilitas, Leverage, dan Tipe Kepemilikan Perusahaan Terhadap Luas Voluntary Disclosure Laporan Keuangan Tahunan. Proceeding Pesat, 2, ISSN : 1858-2559, A53-A61.

Susiana dan Arleen Herawaty. 2007. Analisis Pengaruh Independensi, Mekanisme Corporate Governance, dan Kualitas Audit terhadap Integritas Laporan Keuangan. Jurnal dan Proceding SNA Simposium Nasional Akuntansi. 10.

Tjager, I Nyoman, et al. 2003. Corporate Governance: Tantangan dan Kesempatan bagi Komunitas Bisnis Indonesia. PT. Prenhallindo, Jakarta.

Veronica, Sylvia dan Sidharta Utama. 2008. Type of Earnings Management and The Effect of Ownership Structure, Firm size, and Corporate-Governance Practices: Evidence from Indonesia. The International Journal of Accounting. 43(1):127.

World Bank. 1999. Corporate Governance: Framework for Implementation, Overview. www.worldbank.org.

Yermarck, David. 1996. Higher Market Valuation of Companies with a Small Board of Directors. Journal of Financial Economis. 40(2):185-211.

Yih Yang, Chi, et al. 2008. Managerial Ownership Structure and Earnings Management. Journal of Financial Reporting and Accounting. 40(6):35-53. 